\title{
Galbibacter mesophilus gen. nov., sp. nov., a novel member of the family Flavobacteriaceae
}

\author{
Shams Tabrez Khan, Yasuyoshi Nakagawa and Shigeaki Harayama \\ Biological Resource Center (NBRC), National Institute of Technology and Evaluation (NITE), \\ 2-5-8 Kazusa-kamatari, Kisarazu, Chiba 292-0818, Japan
}

Correspondence

Shams Tabrez Khan

shams-tabrez-khan@nite.go.jp

\begin{abstract}
A Gram-negative, yellow-pigmented, rod-shaped bacterial strain (Mok-17 ${ }^{\top}$ ) was isolated from marine sediment sampled in Okinawa Island, Japan. Based on analysis of the almost complete sequence of its $16 \mathrm{~S}$ rRNA gene, strain Mok-1 $7^{\top}$ was found to belong to the family Flavobacteriaceae. Strain Mok-1 $7^{\top}$ showed highest $16 \mathrm{~S}$ rRNA gene sequence similarity (91\%) to Leeuwenhoekiella marinoflava and Robiginitalea biformata. In a phylogenetic tree based on the 16S rRNA gene, strain Mok $-17^{\top}$ formed a deep branch distinct from all other organisms in the family Flavobacteriaceae. The major quinone was MK-6 and the major fatty acids were iso-15:0,

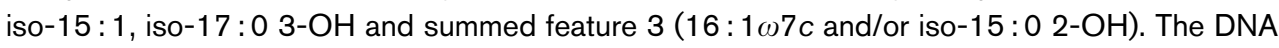
$\mathrm{G}+\mathrm{C}$ content was $37 \mathrm{~mol} \%$. The phylogenetic distance to the type strains of all recognized species in the family Flavobacteriaceae and the phenotypic properties of strain Mok-17 supported its classification as representing a novel species in a new genus, for which the name Galbibacter mesophilus gen. nov., sp. nov. is proposed. The type strain is Mok-1 $7^{\top}(=\mathrm{NBRC}$ $101624^{\top}=$ CIP $109219^{\top}$ ).
\end{abstract}

Bacteria belonging to the phylum Bacteroidetes are present in high numbers in marine environments (Glöckner et al., 1999; Brown \& Bowman, 2001) where they perform different functions of ecological importance. Their possible roles in the carbon cycle (Abell \& Bowman, 2005), degradation of dissolved and particulate organic matter (Cottrell \& Kirchman, 2000; Davey et al., 2001), fish pathology (Bernardet, 1998) and algicidal activity (Maeda et al., 1998) have been discussed. Comprising more than 50 genera at the time of writing, the family Flavobacteriaceae is one of the major branches of the phylum Bacteroidetes. Recently, new members of the family have been isolated from various marine environments (Nedashkovskaya et al., 2003, 2004, 2005). Our group has also characterized several novel species in the family, mostly from sandy sediments collected from the Pacific coasts of Japan (Khan et al., 2006a, b, c, 2007).

Here we describe the isolation of a new strain, designated Mok- $17^{\mathrm{T}}$, from a marine sediment sample collected in Okinawa Island, Japan. The sample was diluted in artificial seawater (ASW; Naigai Chemicals) and aliquots $(0.1 \mathrm{ml})$ of serial dilutions were plated on marine agar 2216 (MA; Difco). Strain Mok- $17^{\mathrm{T}}$ was one of the yellow colonies that grew on the plates. Unless mentioned otherwise, plates or

Abbreviations: ML, maximum-likelihood; MP, maximum-parsimony; $\mathrm{NJ}$, neighbour-joining.

The GenBank/EMBL/DDBJ accession number for the 16S rRNA gene sequence of strain Mok-17 $17^{\top}$ is AB255367. slants of half-strength MA (HSMA) diluted with ASW were used for routine cultivation at $30^{\circ} \mathrm{C}$. For long-term preservation at $-80{ }^{\circ} \mathrm{C}$, bacterial cells were suspended in ASW with $20 \%(\mathrm{v} / \mathrm{v})$ glycerol.

Template DNA for $16 \mathrm{~S}$ rRNA gene amplification was prepared by using Prepman Ultra (Applied Biosystems). The pair of universal primers $27 \mathrm{f}$ and $1492 \mathrm{r}$ was used to amplify the portion of the $16 \mathrm{~S}$ rRNA gene corresponding to positions 8-1492 in the Escherichia coli 16S rRNA gene sequence (Brosius et al., 1978). The amplified fragment was sequenced directly by using a BigDye Terminator v3.1 cycle sequencing kit and an ABI PRISM 3100 Genetic Analyzer (Applied Biosystems). The ATGC program (Genetyx) was used for sequence editing and assembly. The assembled sequence was then compared with the 16S rRNA gene sequences in the DNA Database of Japan (DDBJ) using BLAST searches (Altschul et al., 1990) and was aligned with related sequences by using CLUSTAL X (Thompson et al., 1997). Phylogenetic trees were inferred by using the neighbour-joining (NJ; Saitou \& Nei, 1987), maximum-parsimony (MP; Swofford, 2000) and maximum-likelihood (ML; Adachi \& Hasegawa, 1996) algorithms. The topology of the trees was evaluated by bootstrap resampling analysis (Felsenstein, 1985) of 1000 replicates for NJ and 100 replicates for MP and ML. The BLAST search result clearly indicated that strain Mok- $17^{\mathrm{T}}$ represented a member of the family Flavobacteriaceae. It shared highest $16 \mathrm{~S}$ rRNA gene sequence similarity (92\%) with an unclassified bacterium, 'Flavobacterium' sp. (DDBJ accession no. AJ244702). Strain Mok-17 ${ }^{\mathrm{T}}$ showed highest 
$16 \mathrm{~S}$ rRNA gene sequence similarity to recognized species of $91 \%$ with both Leeuwenhoekiella marinoflava (DDBJ accession no. AY167315) and Robiginitalea biformata (DDBJ accession no. AY424900). Pairwise 16S rRNA gene sequence comparison of strain Mok- $17^{\mathrm{T}}$ with other recognized members of the family Flavobacteriaceae revealed similarities of only $80-91 \%$. In an NJ tree based on $16 \mathrm{~S}$ rRNA gene sequences, strain Mok- $17^{\mathrm{T}}$ formed a novel lineage in the family Flavobacteriaceae, although the branching order of the lineage was not strongly supported by bootstrap analysis (Fig. 1). Similar results were obtained with MP and ML analyses (data not shown).

Standard methods were used for the characterization of strain Mok- $17^{\mathrm{T}}$ as described below and elsewhere (Khan et al., 2006a). Cell morphology was observed under an Olympus light microscope (CX41LF) without staining and after Gram-staining performed as described by Cowan \& Steel (1993). Gliding motility was tested by observing the spread of colony edges on MA plates (Perry, 1973) and by

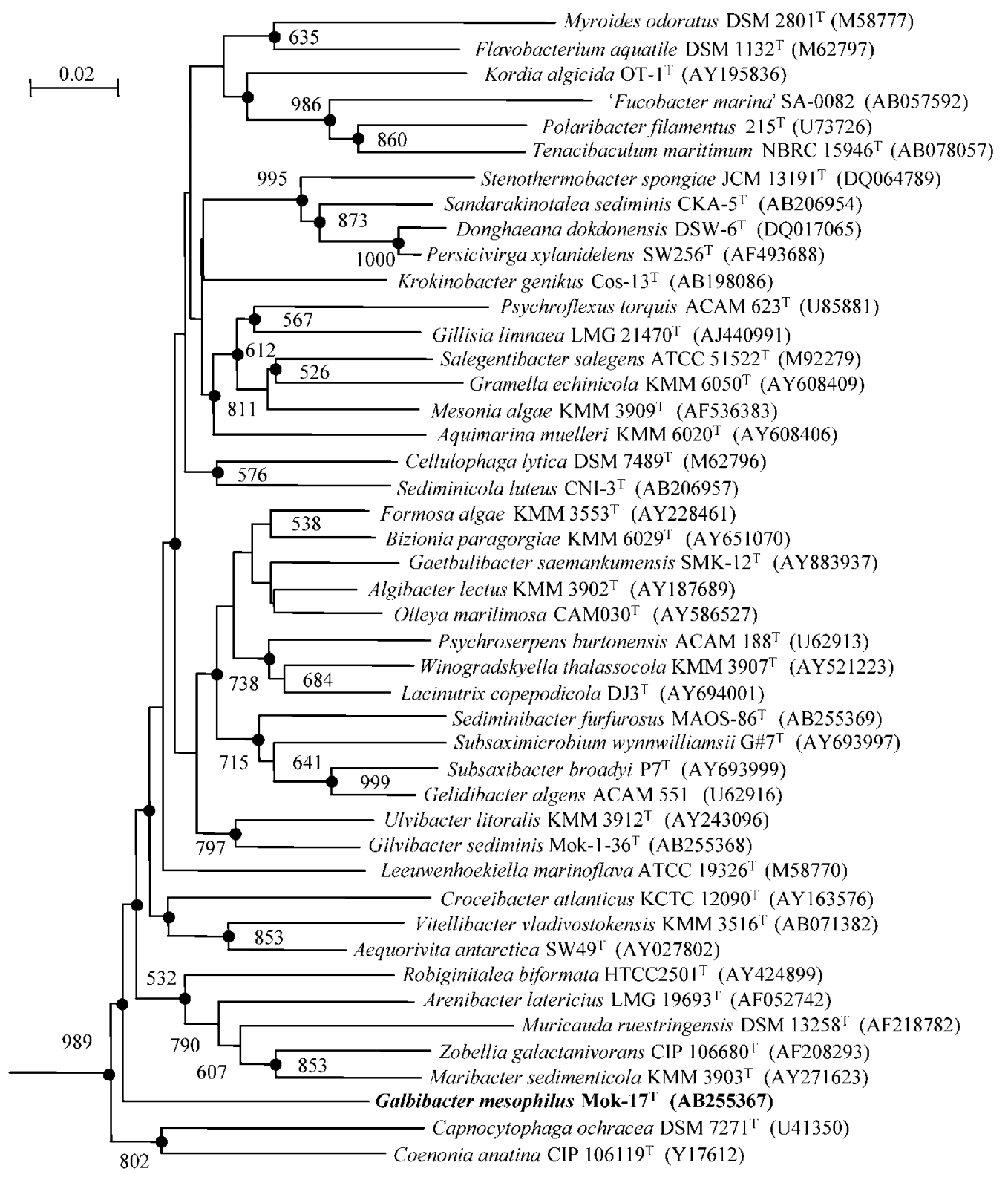

Fig. 1. NJ tree based on $16 \mathrm{~S}$ rRNA gene sequences of strain Mok-17 $7^{\top}$ and related taxa in the family Flavobacteriaceae. Numbers indicate bootstrap values (calculated from 1000 resampled units) of greater than 500. Flexibacter flexilis NBRC 16028 (DDBJ accession no. AB078054; not shown) was used as the outgroup. Closed circles indicate nodes that were also recovered in MP and ML trees. Bar, $0.02 K_{\text {nuc }}$. 
microscopic observation of hanging drops of a marine broth 2216 (MB; Difco) culture (Bernardet et al., 2002) under a $1000 \times$ oil-immersion objective (Olympus CX41LF). The absorption spectrum $(260-700 \mathrm{~nm})$ of an acetone extract of the cells was obtained with a Shimadzu UV-visible spectrophotometer (UV-1650 PC) to assess the presence of carotenoid pigment(s). The bathochromic shift test with $20 \%$ $\mathrm{KOH}(\mathrm{w} / \mathrm{v})$ was performed for the detection of flexirubintype pigments (Fautz \& Reichenbach, 1980). Growth at different temperatures $(4,10,20,30,35,37,40,42$ and $45^{\circ} \mathrm{C}$ ) was assessed on HSMA plates. Salt tolerance was tested in $\mathrm{MB}$ with final $\mathrm{NaCl}$ concentrations adjusted to 3, 5, $6,7,8,9,10$ and $15 \%(w / v)$. Growth was also tested in onefifth-strength LB [2 g Bacto tryptone (Difco) and $1 \mathrm{~g}$ Bacto yeast extract (Difco) dissolved in a final volume of $1000 \mathrm{ml}]$ containing 0, 30, 50 and $70 \%(\mathrm{v} / \mathrm{v})$ ASW. Cells from a 2-day-old HSMA culture were spotted on a glass slide and were flooded with $3 \%$ hydrogen peroxide (v/v) to test for the presence of catalase. The presence of oxidase was tested by spotting a cell suspension (in sterile water) on a cytochrome oxidase strip (Nissui Pharmaceuticals). MB solidified with $1.5 \%$ carrageenan (Type I; Sigma) or agar was used to test the ability of the strain to degrade these molecules. Degradation of cellulose was tested by immersing cellulose strips (Whatman No. 1 paper) in a culture of strain Mok$17^{\mathrm{T}}$ in one-fifth-strength LBM (one-fifth-strength LB prepared with ASW) at $30^{\circ} \mathrm{C}$ for 1 month. Degradation of carboxymethylcellulose (CM-cellulose) was tested by observing the liquefaction of one-fifth-strength LBM solidified with $3 \%$ (w/v) CM-cellulose (High Viscosity; Sigma), while the methods described by Cowan \& Steel (1993) were used to test for the degradation of starch, gelatin, chitin, casein and DNA. The recommendations of the manufacturer were followed for the API 20NE tests (bioMérieux) except that inocula were prepared by suspending cells in sterile ASW. The GN2 MicroPlate system (Biolog) was used to test for the utilization of 95 different carbon sources. Inocula were prepared as suggested by Rüger \& Krambeck (1994) and the microplate was incubated at $30^{\circ} \mathrm{C}$ for $26-30 \mathrm{~h}$ after inoculation.

The Sherlock Microbial Identification system (MIDI) was used for the analysis of fatty acid methyl esters of strain Mok- $17^{\mathrm{T}}$ cultivated on MA for $82 \mathrm{~h}$ at $20^{\circ} \mathrm{C}$. The predominant cellular fatty acids were iso- $17: 03-\mathrm{OH}$, iso- $15: 0$, iso- $15: 1$ and summed feature $3(16: 1 \omega 7 c$ and/or iso- $15: 0$ $2-\mathrm{OH})$. The detailed fatty acid profiles of strain Mok- $17^{\mathrm{T}}$ and related organisms are given in Table 1. Isoprenoid quinones were extracted and analysed according to the protocol of Nakagawa \& Yamasato (1993).

Genomic DNA was prepared according to the protocol of Minamisawa (1990). The HPLC method of Mesbah et al. (1989) was used to determine the $\mathrm{G}+\mathrm{C}$ content of the chromosomal DNA.

Table 2 lists the phenotypic characteristics that can be used to differentiate strain Mok- $17^{\mathrm{T}}$ from the three recognized Leeuwenhoekiella species and $R$. biformata.
Table 1. Fatty acid profiles (\% of total) of strain Mok-1 $7^{\top}$, the three recognized Leeuwenhoekiella species and $R$. biformata

Taxa: 1, strain Mok-17 ; 2, Leeuwenhoekiella (data from Pinhassi et al., 2006); 3, R. biformata HTCC2501 ${ }^{\mathrm{T}}$ (Cho \& Giovannoni, 2004). Abbreviations: tr, trace (fatty acids amounting to less than $1 \%)$; ND, not detected.

\begin{tabular}{|c|c|c|c|}
\hline Fatty acid & 1 & 2 & 3 \\
\hline $15: 0$ & ND & $9-12$ & $5-6$ \\
\hline $15: 03-\mathrm{OH}$ & $\mathrm{ND}$ & $2-3$ & $\operatorname{tr}$ \\
\hline anteiso- $15: 0$ & $\operatorname{tr}$ & $1-4$ & $3-4$ \\
\hline iso- $15: 0$ & 16 & $17-19$ & $24-28$ \\
\hline iso- $15: 1$ & 17 & $11-14^{*}$ & $14-21$ \\
\hline $15: 1 \omega 6 c$ & 3 & 1 & $\operatorname{tr}$ \\
\hline iso- $15: 03-\mathrm{OH}$ & 7 & $2-3$ & 4 \\
\hline $16: 0$ & $\operatorname{tr}$ & $1-2$ & 1 \\
\hline iso- $16: 0$ & $\operatorname{tr}$ & 1 & $\operatorname{tr}$ \\
\hline iso- $16: 03-\mathrm{OH}$ & $\operatorname{tr}$ & $4-7$ & 1 \\
\hline iso- $16: 1$ & 1 & $2^{*}$ & $\operatorname{tr}$ \\
\hline iso- $17: 0$ & ND & ND & 1 \\
\hline $17: 02-\mathrm{OH}$ & $\operatorname{tr}$ & ND & 1 \\
\hline iso- $17: 03-\mathrm{OH}$ & 19 & $13-21$ & $25-27$ \\
\hline anteiso-17:0 $3-\mathrm{OH}$ & ND & $5-7$ & ND \\
\hline $17: 1 \omega 6 c$ & 2 & ND & $\operatorname{tr}$ \\
\hline iso- $17: 1 \omega 7 c$ & ND & $2-3$ & ND \\
\hline iso- $17: 1 \omega 9 c$ & 9 & $\mathrm{ND}$ & $\operatorname{tr}$ \\
\hline Summed feature $3 \dagger$ & 15 & $10-13^{*}$ & 4 \\
\hline Summed feature $4 \dagger$ & 2 & $\mathrm{ND}$ & ND \\
\hline
\end{tabular}

${ }^{*}$ Some of the fatty acids have been identified more precisely by

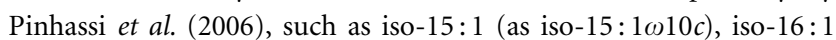

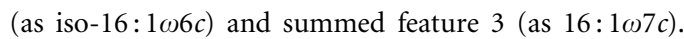

$\dagger$ Summed features consist of one or more fatty acids that could not be separated by the MIDI system. Summed feature 3 comprised $16: 1 \omega 7 c$ and/or iso-15:0 2-OH. Summed feature 4 comprised iso$17: 1 \mathrm{I}$ and/or anteiso-17:1 B.

Other phenotypic characteristics of strain $\mathrm{Mok}-17^{\mathrm{T}}$ are given in the genus and species descriptions. Based on the large phylogenetic distances and differential phenotypic characteristics, it is proposed that strain Mok- $17^{\mathrm{T}}$ be classified as representing a novel species of a new genus in the family Flavobacteriaceae, for which the name Galbibacter mesophilus gen. nov., sp. nov. is proposed.

\section{Description of Galbibacter gen. nov.}

Galbibacter (Gal.bi.bac'ter. L. adj. galbus yellow; N.L. masc. n. bacter rod; N.L. masc. n. Galbibacter a yellow bacterium).

Cells are Gram-negative rods. Catalase- and oxidasepositive. The main respiratory quinone is menaquinone- 6 . Major fatty acids are iso- $17: 03-\mathrm{OH}$, iso- $15: 0$, iso- $15: 1$ and summed feature $3(16: 1 \omega 7 c$ and/or iso-15:0 2-OH). Member of the family Flavobacteriaceae. The type species is Galbibacter mesophilus. 
Table 2. Differential phenotypic characteristics of strain Mok $-17^{\top}$, members of the genus Leeuwenhoekiella and $R$. biformata

Taxa: 1, strain Mok- $17^{\mathrm{T}}$; 2, Leeuwenhoekiella (data from Pinhassi et al., 2006); 3, R. biformata (Cho \& Giovannoni, 2004). Symbols: + , positive reaction; $(+)$, weakly positive reaction; - , negative reaction.

\begin{tabular}{|lccc|}
\hline Characteristic & $\mathbf{1}$ & $\mathbf{2}$ & $\mathbf{3}$ \\
\hline Gliding motility & $-\star$ & + & - \\
Growth: & & & \\
$\quad$ At $42{ }^{\circ} \mathrm{C}$ & + & - & + \\
With $15 \% \mathrm{NaCl}$ & - & + & - \\
Degradation of: & & & - \\
$\quad$ Gelatin & + & + & - \\
$\quad$ Casein & $(+)$ & + & - \\
Nitrate reduction & + & - & $55-56$ \\
DNA G+C content $(\mathrm{mol} \%)$ & 37 & $35-43$ & \\
\hline
\end{tabular}

*Although gliding motility was not observed in hanging-drop preparations of strain Mok- $17^{\mathrm{T}}$, the edge of some colonies showed swarming growth after prolonged incubation on MA.

\section{Description of Galbibacter mesophilus sp. nov.}

Galbibacter mesophilus [me.so.phi'lus. Gr. adj. mesos middle; Gr. adj. philos loving; N.L. masc. adj. mesophilus middle (temperature)-loving, i.e. mesophilic].

The description is as for the genus with the following additional properties. Cells are $0.5-0.7 \mu \mathrm{m}$ in width and $1.0-3.0 \mu \mathrm{m}$ in length. Colonies on MA are yellow with irregular margins after 3 days incubation at $30^{\circ} \mathrm{C}$. The edge of some colonies may show swarming growth; however, gliding motility is not observed in hanging-drop preparations. Carotenoid-type pigments are produced but flexirubin-type pigments are not. Growth occurs at temperatures between 10 and $42{ }^{\circ} \mathrm{C}$, with optimal growth at $25-30^{\circ} \mathrm{C}$. No growth is observed at 4 or $45^{\circ} \mathrm{C}$. Growth occurs in the presence of $30-70 \%(\mathrm{v} / \mathrm{v})$ ASW but not in the absence of seawater. Growth occurs in the presence of 3-7\% NaCl (w/v) and optimally with $3-5 \% \mathrm{NaCl}(\mathrm{w} / \mathrm{v})$. Positive for the degradation of starch, aesculin and gelatin, reduction of nitrate to nitrite, and production of $\beta$-galactosidase. Negative for arginine dihydrolase activity and for the degradation of agar, carrageenan, urea, arginine, DNA, chitin, cellulose and CMcellulose. Weakly positive for the production of indole from tryptophan and for casein degradation. Acid is not produced from glucose. The following compounds are utilized: $\alpha$-cyclodextrin, dextrin, cellobiose, D-fructose, D-galactose, gentiobiose, $\alpha$-D-glucose, $\alpha$-D-lactose, lactulose, maltose, D-mannose, D-melibiose, methyl $\beta$-D-glucoside, D-raffinose, sucrose, D-trehalose, turanose, L-alanyl glycine, L-asparagine, L-aspartic acid, L-glutamic acid, glycyl L-glutamic acid, L-proline, L-serine and L-threonine. The detailed fatty acid composition is given in Table 1. The DNA G+C content of the type strain is $37 \mathrm{~mol} \%$.
The type strain, Mok- $17^{\mathrm{T}} \quad\left(=\mathrm{NBRC} \quad 101624^{\mathrm{T}}=\mathrm{CIP}\right.$ $109219^{\mathrm{T}}$ ), was isolated from a marine sediment sample collected in Okinawa Island, Japan.

\section{Acknowledgements}

This work was supported by the New Energy and Industrial Technology Development Organization (NEDO grant no. 04000182-0).

\section{References}

Abell, G. C. J. \& Bowman, J. P. (2005). Ecological and biogeographic relationships of class Flavobacteria in the Southern Ocean. FEMS Microbiol Ecol 51, 265-277.

Adachi, J. \& Hasegawa, M. (1996). MOLPHY Version 2.3-Programs for Molecular Phylogenetics Based on Maximum Likelihood. Computer Science Monograph no. 28. Tokyo: Institute of Statistical Mathematics.

Altschul, S. F., Gish, W., Miller, W., Myers, E. W. \& Lipman, D. J. (1990). Basic local alignment search tool. J Mol Biol 215, 403-410.

Bernardet, J.-F. (1998). Cytophaga, Flavobacterium, Flexibacter and Chryseobacterium infections in cultured marine fish. Fish Pathol 33, 229-238.

Bernardet, J.-F., Nakagawa, Y. \& Holmes, B. (2002). Proposed minimal standards for describing new taxa of the family Flavobacteriaceae and emended description of the family. Int J Syst Evol Microbiol 52, 1049-1070.

Brosius, J., Palmer, M. L., Kennedy, P. J. \& Noller, H. F. (1978). Complete nucleotide sequence of a $16 \mathrm{~S}$ ribosomal RNA gene from Escherichia coli. Proc Natl Acad Sci U S A 75, 4801-4805.

Brown, M. V. \& Bowman, J. P. (2001). A molecular phylogenetic survey of sea-ice microbial communities (SIMCO). FEMS Microbiol Ecol 35, 267-275.

Cho, J.-C. \& Giovannoni, S. J. (2004). Robiginitalea biformata gen. nov., sp. nov., a novel marine bacterium in the family Flavobacteriaceae with a higher $\mathrm{G}+\mathrm{C}$ content. Int J Syst Evol Microbiol 54, 1101-1106.

Cottrell, M. T. \& Kirchman, D. L. (2000). Natural assemblages of marine proteobacteria and members of the Cytophaga-Flavobacter cluster consuming low- and high-molecular-weight dissolved organic matter. Appl Environ Microbiol 66, 1692-1697.

Cowan, S. T. \& Steel, K. J. (1993). Manual for the Identification of Medical Bacteria, 3rd edn. London: Cambridge University Press.

Davey, K. E., Kirby, R. R., Turley, C. M., Weightman, A. J. \& Fry, J. C. (2001). Depth variation of bacterial extracellular enzyme activity and population diversity in the northeastern North Atlantic Ocean. DeepSea Res Part II 48, 1003-1017.

Fautz, E. \& Reichenbach, H. (1980). A simple test for flexirubin-type pigments. FEMS Microbiol Lett 8, 87-91.

Felsenstein, J. (1985). Confidence limits on phylogenies: an approach using the bootstrap. Evolution 39, 783-791.

Glöckner, F. O., Fuchs, B. M. \& Amann, R. (1999). Bacterioplankton compositions of lakes and oceans: a first comparison based on fluorescence in situ hybridization. Appl Environ Microbiol 65, 3721-3726.

Khan, S. T., Nakagawa, Y. \& Harayama, S. (2006a). Krokinobacter gen. nov., with three novel species, in the family Flavobacteriaceae. Int J Syst Evol Microbiol 56, 323-328. 
Khan, S. T., Nakagawa, Y. \& Harayama, S. (2006b). Sediminicola luteus gen. nov., sp. nov., a novel member of the family Flavobacteriaceae. Int J Syst Evol Microbiol 56, 841-845.

Khan, S. T., Nakagawa, Y. \& Harayama, S. (2006c). Sandarakinotalea sediminis gen. nov., sp. nov., a novel member of the family Flavobacteriaceae. Int J Syst Evol Microbiol 56, 959-963.

Khan, S. T., Nakagawa, Y. \& Harayama, S. (2007). Sediminibacter furfurosus gen. nov., sp. nov. and Gilvibacter sediminis gen. nov., sp. nov., novel members of the family Flavobacteriaceae. Int J Syst Evol Microbiol 57, 265-269.

Maeda, T., Murakami, M., Ohsugi, S., Furushita, M., Mitsutani, A. \& Shiba, T. (1998). Perspectives of the development of $16 \mathrm{~S}$ rDNA probe specific for algicidal and/or algal-lytic gliding bacteria. Fish Sci 64, 861-865.

Mesbah, M., Premachandran, U. \& Whitman, W. B. (1989). Precise measurement of the $\mathrm{G}+\mathrm{C}$ content of deoxyribonucleic acid by high-performance liquid chromatography. Int J Syst Bacteriol 39, 159-167.

Minamisawa, K. (1990). Division of rhizobitoxine-producing and hydrogen-uptake positive strains of Bradyrhizobium japonicum by nifDKE sequence divergence. Plant Cell Physiol 31, 81-89.

Nakagawa, Y. \& Yamasato, K. (1993). Phylogenetic diversity of the genus Cytophaga revealed by $16 \mathrm{~S}$ rRNA sequencing and menaquinone analysis. J Gen Microbiol 139, 1155-1161.

Nedashkovskaya, O. I., Suzuki, M., Vysotskii, M. V. \& Mikhailov, V. V. (2003). Vitellibacter vladivostokensis gen. nov., sp. nov., a new member of the phylum Cytophaga-Flavobacterium-Bacteroides. Int J Syst Evol Microbiol 53, 1281-1286.
Nedashkovskaya, O. I., Kim, S. B., Han, S. K., Rhee, M. S., Lysenko, A. M., Falsen, E., Frolova, G. M., Mikhailov, V. V. \& Bae, S. K. (2004). Ulvibacter litoralis gen. nov., sp. nov., a novel member of the family Flavobacteriaceae isolated from the green alga Ulva fenestrata. Int J Syst Evol Microbiol 54, 119-123.

Nedashkovskaya, O. I., Vancanneyt, M., Dawyndt, P., Engelbeen, K., Vandemeulebroecke, K., Cleenwerck, I., Hoste, B., Mergaert, J., Tan, T.-L. \& other authors (2005). Reclassification of [Cytophaga] marinoflava Reichenbach 1989 as Leeuwenhoekiella marinoflava gen. nov., comb. nov. and description of Leeuwenhoekiella aequorea sp. nov. Int J Syst Evol Microbiol 55, 1033-1038.

Perry, L. B. (1973). Gliding motility in some non-spreading flexibacteria. J Appl Bacteriol 36, 227-232.

Pinhassi, J., Bowman, J. P., Nedashkovskaya, O. I., Lekunberri, I., Gomez-Consarnau, L. \& Pedrós-Alió, C. (2006). Leeuwenhoekiella blandensis sp. nov., a genome-sequenced marine member of the family Flavobacteriaceae. Int J Syst Evol Microbiol 56, 1489-1493.

Rüger, H.-J. \& Krambeck, H.-J. (1994). Evaluation of the BIOLOG substrate metabolism system for classification of marine bacteria. Syst Appl Microbiol 17, 281-288.

Saitou, N. \& Nei, M. (1987). The neighbor-joining method: a new method for reconstructing phylogenetic trees. Mol Biol Evol 4, 406-425.

Swofford, D. L. (2000). PAUP ${ }^{*}$ : Phylogenetic analysis using parsimony ( ${ }^{*}$ and other methods), version 4. Sunderland, MA: Sinauer Associates.

Thompson, J. D., Gibson, T. J., Plewniak, F., Jeanmougin, F. \& Higgins, D. G. (1997). The CLUSTAL_X windows interface: flexible strategies for multiple sequence alignment aided by quality analysis tools. Nucleic Acids Res 25, 4876-4882. 